\title{
CROP WATER STRESS INDEX FOR POTATO UNDER SUBSURFACE DRIP IRRIGATION
}

\author{
Abousrie A. Farag*
}

ABSTRACT

The aim of this study was to find out the effects of crop water stress index (CWSI) and soil water content (SWC) under subsurface drip irrigation system on yield and water use efficiency. The CWSI was estimated and SWC was measured under seven irrigation strategies: sustainable deficit irrigation (DI), regulated deficit irrigation (RDI), partial root zone drying (PRD) at two levels i.e. $80 \%$ and $60 \%$ and full irrigation water (FI) (control). The results showed that, the highest SWC and CWSI during the growth season compared with FI were regulated deficit irrigation (RDI) at $80 \%$ followed by PRD at $80 \%$ whereas the lowest ones were DI at $60 \%$ and PRD at $60 \%$. Also, the highest values of yield and water use efficiency were achieved under RDI at 80\% (19.54 tha $\mathrm{ha}^{-1}$ in summer and $21.55 \mathrm{tha^{-1 }}$ in winter) followed by PRD at $80 \%$ whereas the lowest values were achieved under DI and PRD at 60\%. The winter season gave values of yield higher than the corresponding ones in obtained summer season by $17.02 \%$.

Keywords: sustainable deficit irrigation, soil water content, regulated deficit irrigation and partial root zone drying.

\section{INTRODUCTION}

$\mathrm{S}$ hortage of water forced farmers and decision makers to decrease the amount of applied irrigation water, this technique has many strategies e.g. deficit irrigation (DI) and partial dry of root zone (Costa et. al, 2007). Deficit irrigation has been widely implemented as a valuable and sustainable production strategy in dry regions. This practice aims to maximize water productivity and to maximize - yields. DI is successful in increasing water productivity for various crops without causing severe yield reductions. DI requires precise knowledge of crop response to drought stress, as drought tolerance varies considerably by genotype and physiological stage. In developing and optimizing DI strategies, field research should therefore be combined with crop water productivity modeling (Geerts and Raes, 2009).

* Lecturer at Department of Agricultural and Bio-systems Engineering, Faculty of Agriculture, Benha University, Egypt. abousrie.ahmad@fagr.bu.edu.eg 
The use of regulated Deficit irrigation (RDI) strategies is becoming a common practice in areas with low water availability. Little information is available about the effects of RDI on the antioxidant content of fruits. (Buendía et. al., 2008). The effects of RDI on decreasing yield was not significant compared with full irrigation requirements. (Romero et. al., 2004).

Efficient water delivery systems such as drip irrigation can contribute to increasing potential crop yield, improving crop water and fertilizer use efficiency. However, critical management considerations such as subsurface drip irrigation are necessary to attain improved irrigation efficiencies and produce benefits particularly under arid regions. In terms of soil water availability to plants, subsurface drip provided more favorable growth conditions for plant growth and maintained higher soil water content at the root zone, which resulted in a significant higher potato yield compared to surface drip irrigation (Badr et. al., 2010). On the other hand, they found that, reducing the amounts of applied water significantly decreased total potato yield and its components. Under subsurface drip irrigation, reducing amounts of applied water to $80 \%$ ETc gave comparable yield and yield components to surface drip at full irrigation supply, indicating that $20 \%$ irrigation water can be saved without affecting the potato yield. In addition to, subsurface drip recorded higher water use efficiency (WUE) over surface drip irrigation (Badr et. al., 2010).

Partial root-zone irrigation creates a dynamic heterogeneous distribution of soil moisture that may affect the numbers and activities of soil microorganisms. The alternate partial root-zone irrigation (APRI, alternate watering on both sides of the pot) is better than fixed partial root-zone irrigation (FPRI, fixed watering on one side of the pot) due to APRI maintained the best aeration and moisture condition in the soil and enhanced the activities of soil microorganisms, which might also have benefited the plant growth (Wang et al., 2008).

The crop water stress index (CWSI) was linked to soil moisture through the water stress coefficient $K s$ that accounts for reduced crop evapotranspiration when there is a shortage in soil water. A stress recovery coefficient Krec was introduced to account for reduced crop evapotranspiration as the crop recovered from water stress after irrigation 
events (Colaizzi et. al., 2003). Potato fruits (tuber) yield decreased when mean CWSI prior to irrigation exceeded 0.68 in furrow and 0.81 in drip irrigation. The tuber yield was directly correlated with the seasonal CWSI values and the linear equations for furrow and drip irrigation methods, $\mathrm{Y}=$ $-45.82 \mathrm{CWSI}+50.69$ and $\mathrm{Y}=-52.65 \mathrm{CWSI}+58.44$, respectively (Erdem et. al., 2005).

In the last few years there are many Deficit irrigation techniques and some of these techniques are better than others according to the kind of crop and the type of soil, so the aim of this study is to select the best Deficit irrigation technique for potato crop under subsurface drip irrigation system in a clayey soil by using CWSI, soil water content (SWC), yield and water use efficiency as items of cooperation.

\section{MATERIAL AND METHODS}

\section{The experimental site}

This work was carried out at the farm of the Faculty of Agriculture, Benha University, North of Delta, Egypt during the winter and summer growth seasons of 2017 and 2018. Potato crop (Solanum tuberosum L. 'sponta') was planted with the distance of $50 \mathrm{~cm}$ between plants and $\wedge \cdot \mathrm{cm}$ between rows. Lateral lines (in line emitters) were used and the distance between emitters was $50 \mathrm{~cm}$. The drippers lines were put under soil surface by 20 $\mathrm{cm}$. The irrigation efficiency of the irrigation system is assumed to be $95 \%$. Different irrigation depths were simultaneously applied in the different irrigation treatments being the irrigation date decided according to total irrigation requirement of non-stressed situation (FI, correspondent to ETc/ irrigation efficiency). The irrigation treatments were seven, as follows: FI, sustained Deficit irrigation correspondent to 80\% (DI 80) and to 60\% (DI 60) of the first value, regulated Deficit irrigation applied between mid and harvest-stage (after 60 days from planting) for 80\% (RDI 80) and $60 \%$ (RDI 60) and partial root zone drying for the same two thresholds as above (PRD 80 and 60), in sustained mode.

\section{Crop Evapotranspiration}

The potential evapotranspiration $\left(E T_{0}\right)$, was estimated by Benman-Montith equation and crop factor $(K c)$ was selected from FAO56 tables, according to Allen, et. al (1998). The crop evapotranspiration (ETc) was calculated by multiplying the ETo by $K c$. 

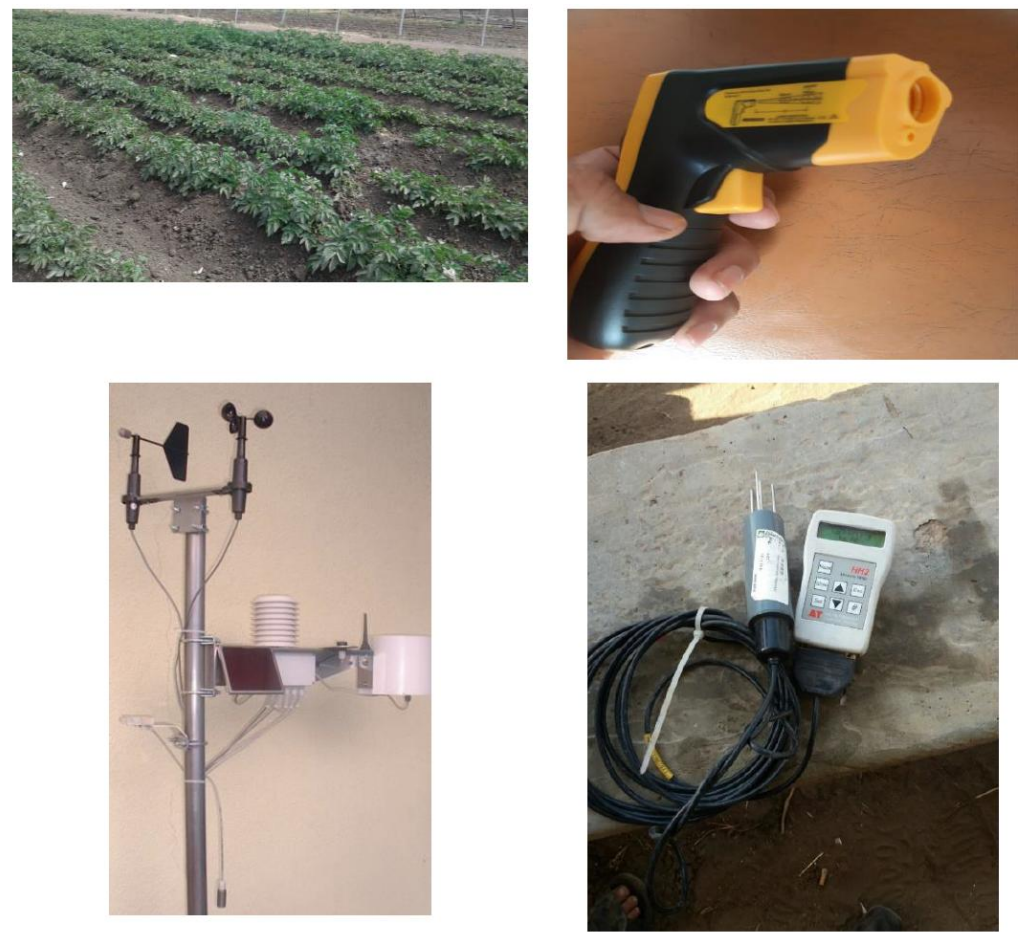

Fig (1): The farm view and the measurements tools

\section{Soil Water Content (SWC)}

Soil water content was measured by WET-2 sensor (soil moisture sensor) and $\mathrm{HH} 2$ moisture meter several times during the growth seasons as shown in Fig. (1).

\section{Crop Water Stress Index (CWSI)}

The crop water stress index (CWSI) was calculated by an empirical method (Equation [1]), as suggested by Idso et al. (1981):

$$
C W S I=\frac{\left(T_{c}-T_{a}\right)-\left(T_{c}-T_{a}\right)_{U L}}{\left(T_{c}-T_{a}\right)_{U L}-\left(T_{c}-T_{a}\right)_{L L}}
$$

where $\mathrm{Tc}$ is the canopy temperature $\left({ }^{\circ} \mathrm{C}\right)$ and $\mathrm{Ta}$ is the air temperature $\left({ }^{\circ} \mathrm{C}\right)$ and LL corresponds to the non-water-stressed baseline (lower baseline), and UL corresponds to the non-transpiring upper baseline. The lower baseline was determined using data collected only from the unstressed treatments (full irrigation, FI). The upper baseline was computed according to the procedures explained by Idso et al. (1981). 
The CWSI values range between zero (condition of optimal crop water status) and one (condition of high crop water stress).

\section{Yield and Water Use Efficiency.}

The marketable yield of potato in $\mathrm{Mg} \mathrm{ha}^{-1}$ was measured at the end of growth seasons of winter and summer of 2017 and 2018 as shown in Table (2). The yield was measured for each replicate of treatments. The area of each replicate was i.e. $9.6 \mathrm{~m}^{2}(0.8 \mathrm{~m} \times 12 \mathrm{~m})$.

Water use efficiency by $\mathrm{kg} \mathrm{m}^{-3}$ was determined by dividing the yield $(\mathrm{kg}$ $\mathrm{m}^{-2}$ ) multiplied by the total crop evapotranspiration (ETc). ETC in the winter 2017 and 2018 were 165.4 and $119.06 \mathrm{~mm}$, and in the summer 2017 and 2018 they were 271.16 and $310.76 \mathrm{~mm}$.

\section{Statistical Analysis}

The design of the experiment was randomized complete block design (RCBD) and ANOVA- one way and Fisher LSD test applied on the results of SWC, CWSI, Yield and WUE to show the significance of differences at $\mathrm{p}=0.05$.

\section{RESULTS AND DISCUSSION}

\section{Soil Water Content and Crop Evapotranspiration}

Values of the estimated ETC are shown in Figs. (1a to d). The mean value of ETc in summer 2018 was higher than the corresponding one in summer 2017, while in winter the average value of ETc in 2017 was higher than in 2018.

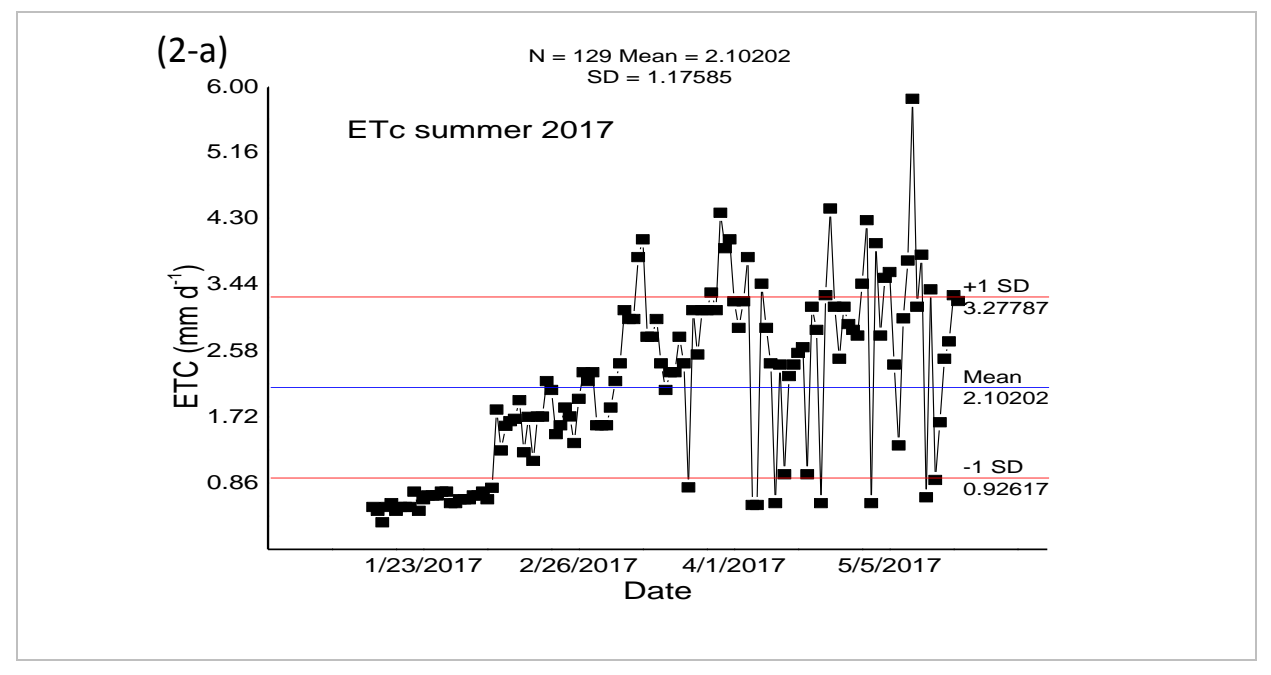




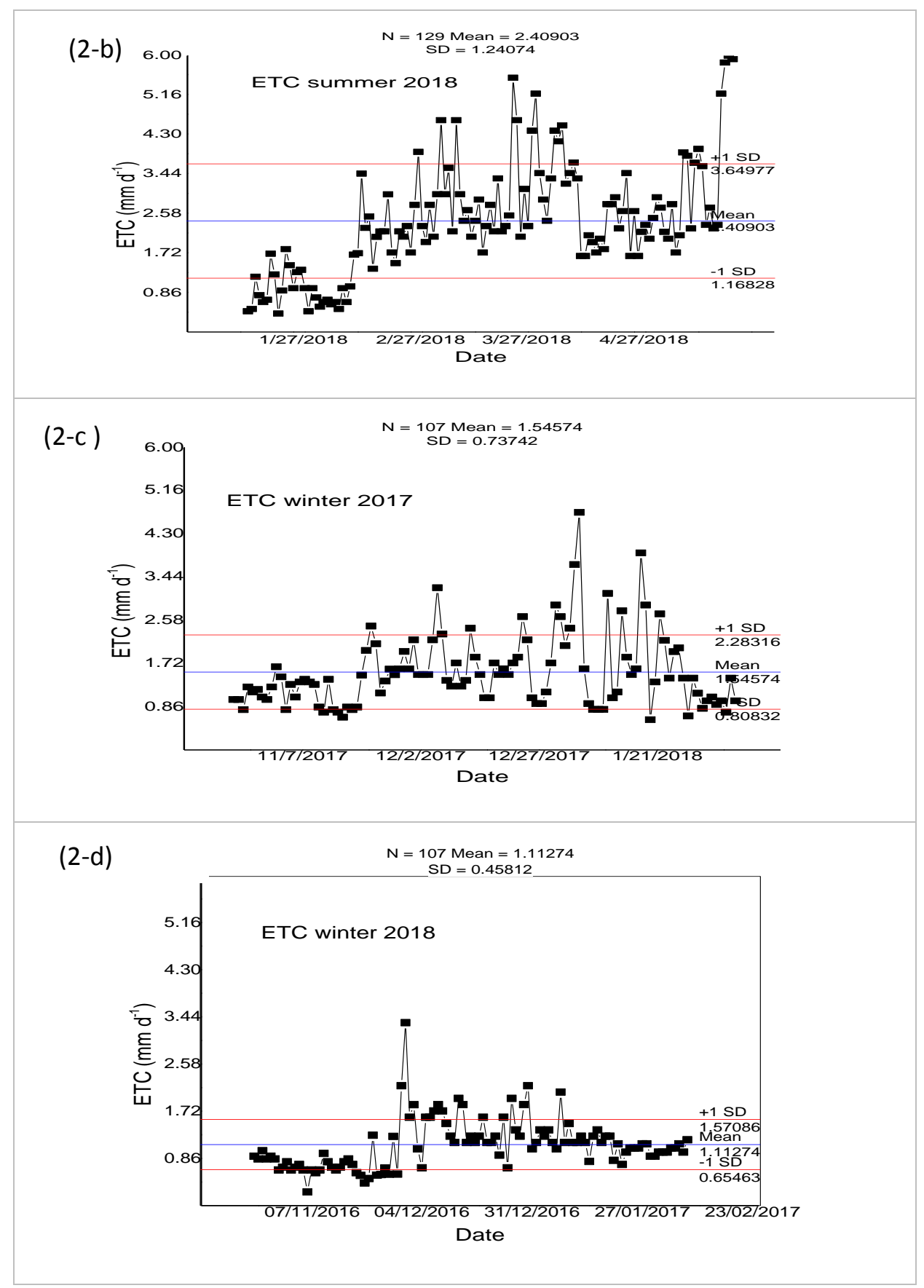

Fig (2): The estimated values of ETc during the growth seasons of summer and winter 2017 and 2018. 
The total soil water expressed in $\left(\mathrm{cm}^{3} \mathrm{~cm}^{3}\right)$ for FI and the six Deficit irrigation treatments varied between FC and the lowest limit of readily

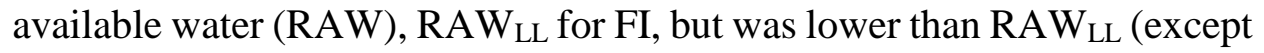
for the early season) for all DI treatments, for both the summer and winter seasons (Figures $3 \mathrm{c}$ to d).and (Figures $3 \mathrm{a}$ to $\mathrm{b}$ ), respectively.

The results in Fig. (3) show that, the highest values of SWC were under FI followed by RDI 80, PRD80 and DI80 whereas the lowest values were under DI 60 and PRD 60. The regulated Deficit irrigation (RDI) technique gave better SWC than sustainable Deficit irrigation (DI). This result is in agree with those of Badr et al, (2010). Moreover, the values of SWC in winter were higher than the corresponding values in summer season, because values of the ETc in winter were less than the corresponding ones in summer as shown in Figures (2 and 3 ).

On the other hand, the values of SWC ranged from 0.26 to $0.33 \mathrm{~cm}^{3} \mathrm{~cm}^{-3}$ in summer and 0.31 to $0.40 \mathrm{~cm}^{3} \mathrm{~cm}^{-3}$ in winter after 2 days of irrigation. Fisher test LSD at 0.05 shows that, in summer season there were significant differences in soil water content among all treatments except for these pairs (RDI60 and PRD80), (DI80 and PRD80) and (DI80 and RDI60). In winter season, there were significant differences in soil water content among all treatments except for the following pairs (RDI80 and RDI60), (DI60 and PRD60), (DI80 and PRD80) and (FI and RDI80). There were also differences but slight ones among all techniques (DI, RDI and PRD) at 80\% and $60 \%$ deficit. Only RDI technique achieved values of SWC equal to FI for level RDI80 in winter season.

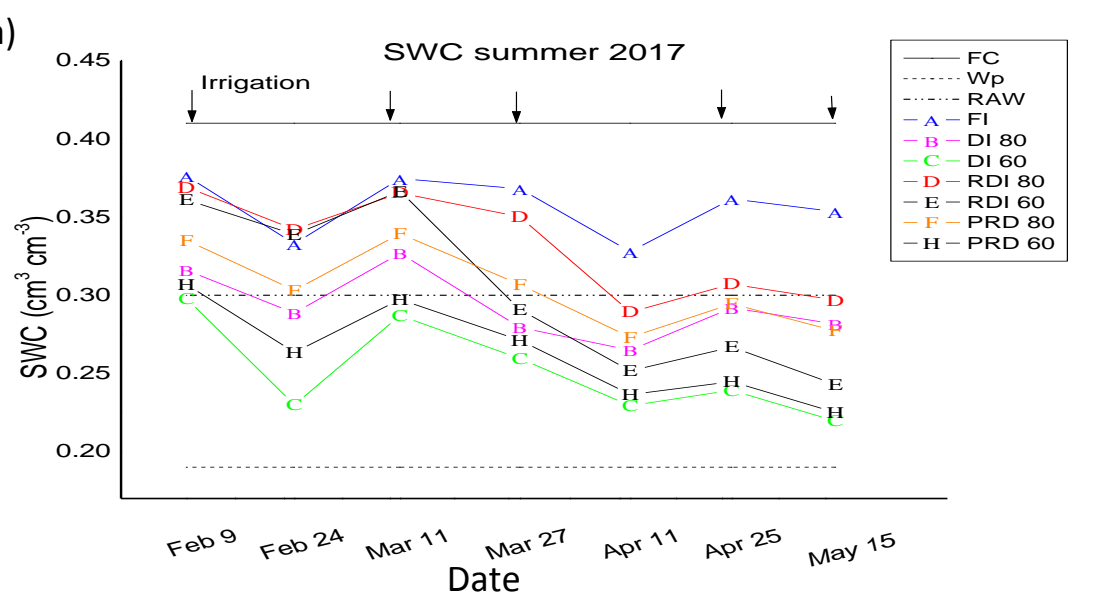




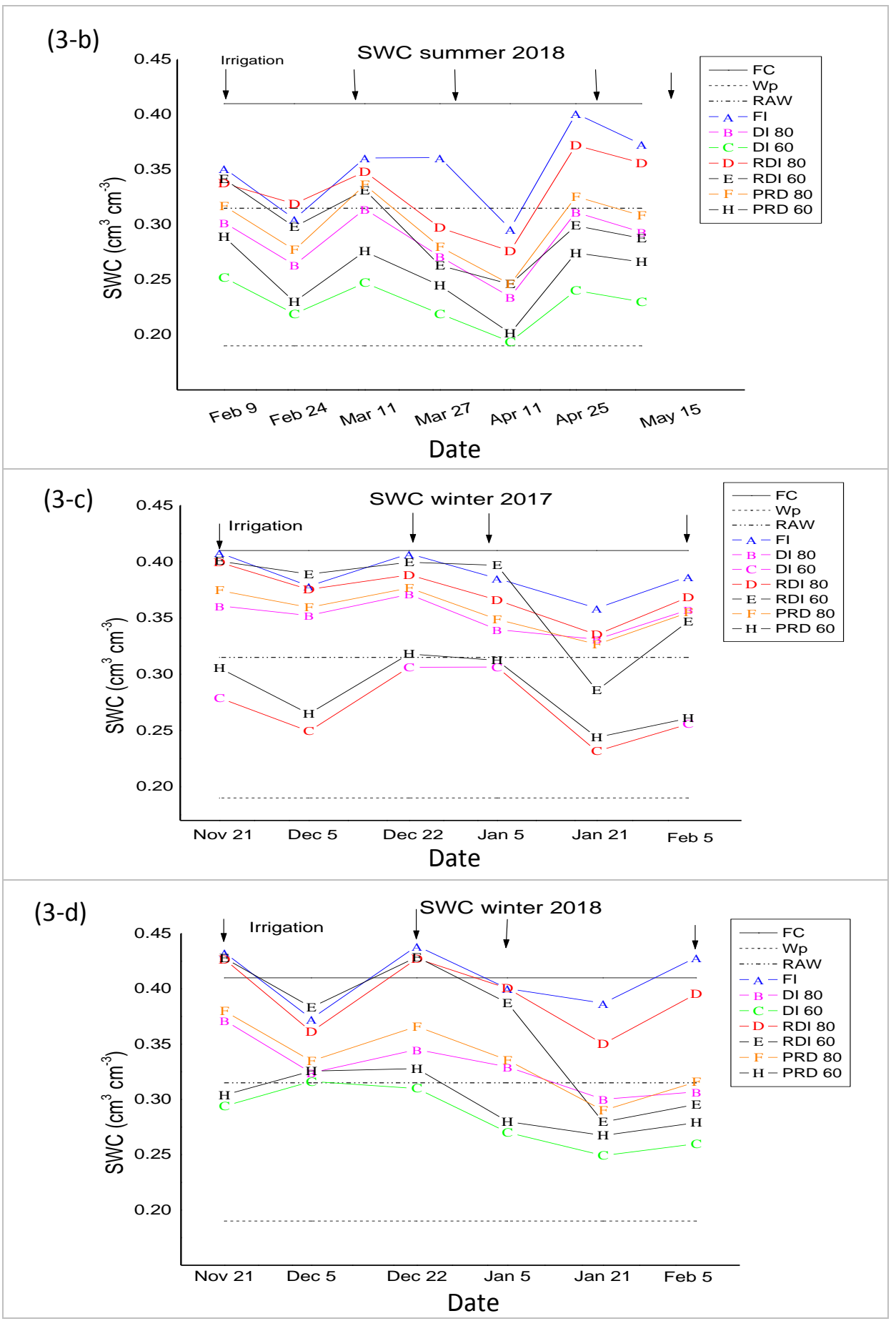

Fig (3): Soil water content during the growing seasons of potato crop 


\section{Crop Water Stress Index (CWSI) Under the Different Studied Treatments}

The CWSI took the same trend of SWC as shown in Figs. (3 and 4). The mean values of CWSI ranged from 0.1 to 0.31 in winter season, while in summer they ranged from 0.33 to 0.54 , this was due to the changes in the amount of applied irrigation water and ETc as shown in Fig. (4).

The statistical analysis of results of CWSI by using Fisher test LSD for all treatments showed that, there weren't significant differences between the following treatments (RDI60 and PRD80), (RDI80 and PRD80), (RDI80 and RDI60), (DI60 and PRD60), (DI80 and PRD80) and (DI80 and RDI60) in both summer and winter seasons, while the differences between DI80 and RDI80 were not significant in summer but significant in winter season.

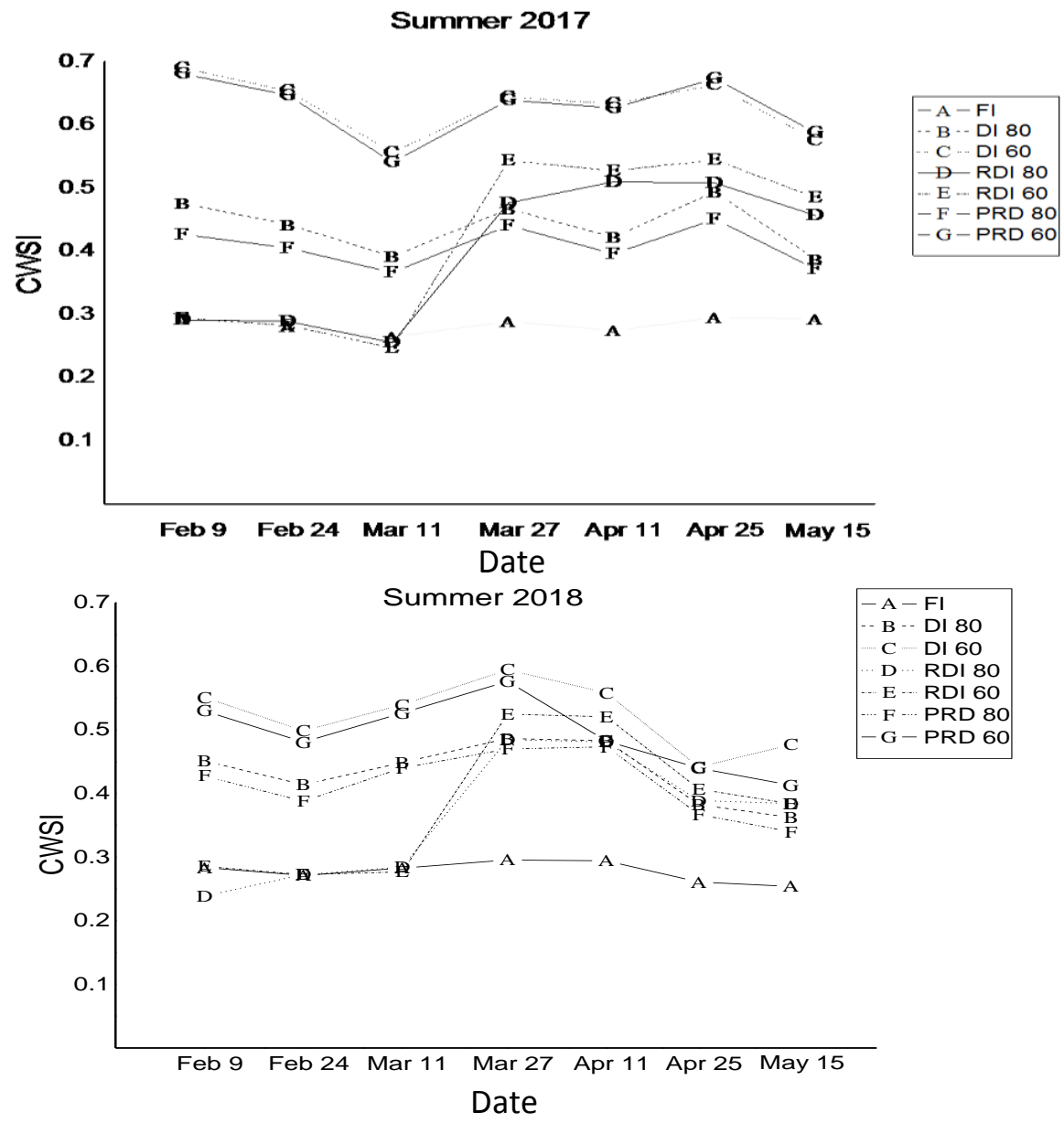

Misr J. Ag. Eng., January 2020 

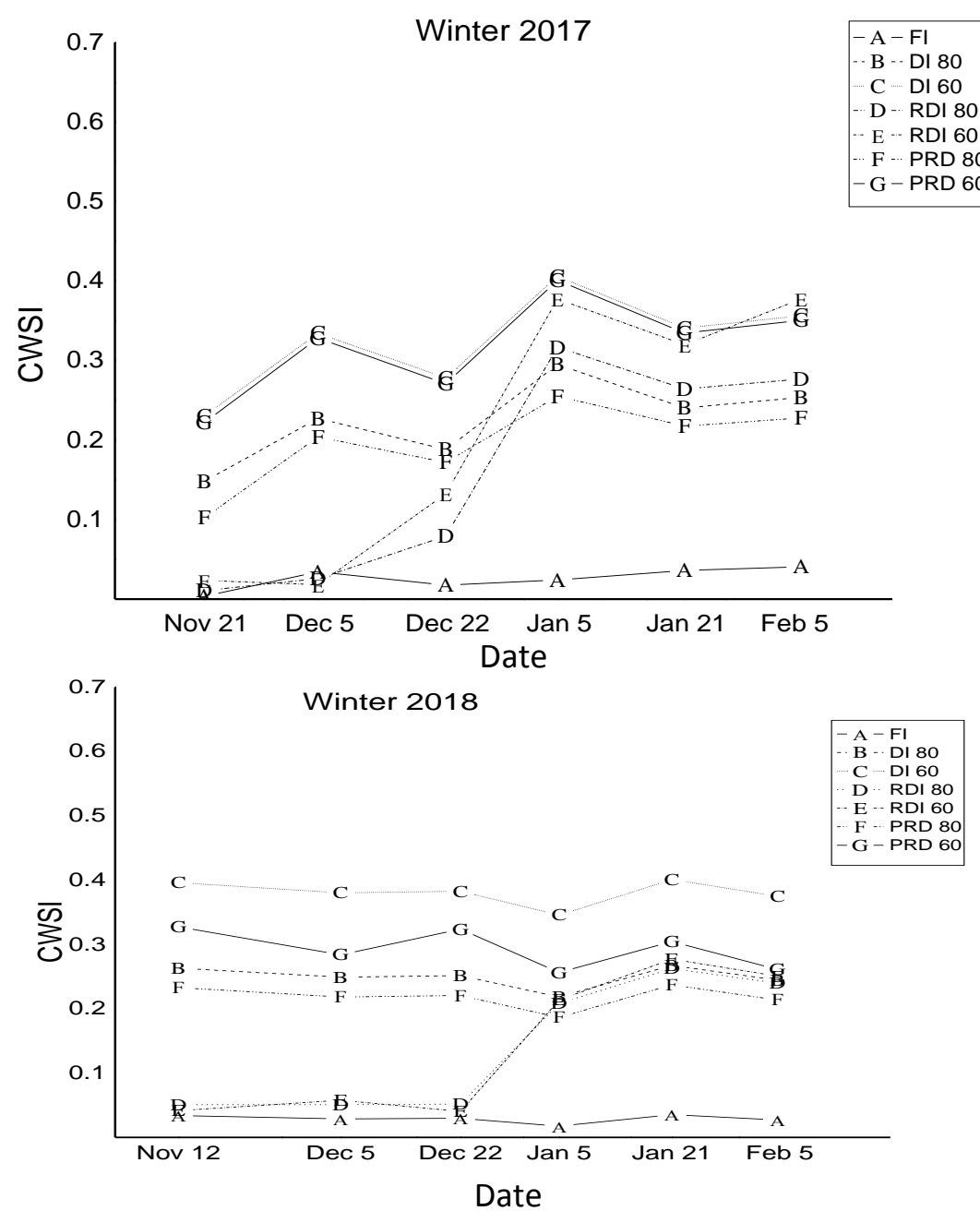

Fig (4): CWSI during the growth season of potato crop

\section{Yield and Water Use Efficiency (WUE)}

The values of total yield of potato under the different irrigation treatments in winter and summer seasons of 2017 and 2018 are presented in Table 2. The results show that, in the winter season the values of yield were higher by $17.02 \%$ than the corresponding one in the summer season. RDI technique decreased the yield by different values ranged from $0.41 \%$ in winter to $2.49 \%$ in summer under RDI 80, while under RDI 60 there were higher decreases in values of yield ranged from $23.9 \%$ (in winter) to $32.75 \%$ (in summer season). Also, under the PRD technique, the yield was 
less than under the RDI by about $9.09 \%$ and $38.4 \%$ under RDI 80 and RDI 60 , respectively.

Table (2). The yield of potato $\left(\mathrm{Mg} \mathrm{ha}^{-1}\right)$ under different irrigation strategies during winter and summer seasons of 2017 and 2018.

\begin{tabular}{lcccc}
\hline Irrigation & \multicolumn{4}{c}{ yield $\left(\mathrm{Mg} \mathrm{ha}^{-1}\right)$} \\
\cline { 2 - 5 } & \multicolumn{2}{c}{2017} & \multicolumn{3}{c}{2018} \\
\cline { 2 - 5 } & Summer & Winter & Summer & Winter \\
\cline { 2 - 5 } FI & 19.67 & 21.42 & 20.42 & 24.08 \\
DI 80\% & 13.52 & 17.41 & 18.09 & 19.48 \\
DI 60\% & 11.28 & 11.45 & 8.53 & 13.13 \\
RDI 80\% & 19.34 & 20.31 & 19.75 & 22.79 \\
RDI 60\% & 11.19 & 16.01 & 13.44 & 17.77 \\
PRD 80\% & 16.83 & 18.94 & 18.67 & 21.29 \\
PRD 60\% & 11 & 12.83 & 13.06 & 14.43 \\
\hline
\end{tabular}

The DI technique achieved the lowest values of yield, where it decreased by about $8.3 \%$ and 9.83 in winter and $17.52 \%$ and $19.76 \%$ in summer under DI 80 and DI 60, respectively. Generally, decrease in irrigationiwater decreased yield by values changed according to the stress values of CWSI for all treatments as shown in Fig.(5).

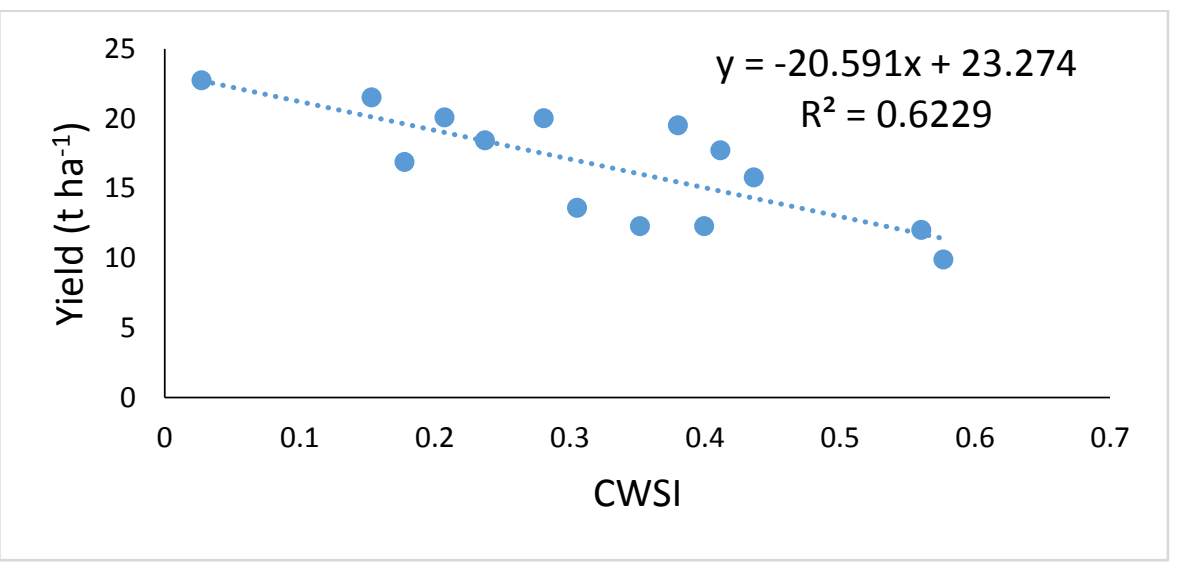

Fig (5): The relationship between CWSI and yield of potato crop.

In summer season the fisher (LSD) test shows that there weren't significant differences in yield between the following pairs of irrigation treatments: 
$\mathrm{PRD}_{60}$ and $\mathrm{RDI}_{60}, \mathrm{PRD}_{60}$ and $\mathrm{DI}_{60}, \underline{\mathrm{PRD}}_{60}$ and $\mathrm{DI}_{80}, \mathrm{PRD}_{80}$ and $\mathrm{RDI}_{80}$, $\mathrm{PRD}_{80}$ and $\mathrm{DI}_{80}, \mathrm{PRD}_{80}$ and FI, $\mathrm{RDI}_{60}$ and $\mathrm{DI}_{60}, \mathrm{RDI}_{80}$ and $\mathrm{DI}_{80}$ and $\mathrm{RDI}_{80}$ and FI. In winter season the fisher (LSD) test shows that, there weren't significant differences in yield between the following pairs: PRD $_{60}$ and $\mathrm{RDI}_{60}, \mathrm{PRD}_{60}$ and $\mathrm{DI}_{60}, \underline{\mathrm{PRD}}_{80}$ and $\mathrm{RDI}_{60}, \mathrm{PRD}_{80}$ and $\mathrm{RDI}_{80}, \mathrm{PRD}_{80}$ and $\mathrm{DI}_{80}, \mathrm{PRD}_{80}$ and FI, RDI 80 and $\mathrm{DI}_{80}$ and $\mathrm{RDI}_{80}$ and FI. Applying water less than FI decreased the total yield. $\mathrm{RDI}_{80}$ and $\mathrm{PRD}_{80}$ achieved yield less than FI, however the difference was not significant. The differences in yield between $\mathrm{PRD}_{60}$ and $\mathrm{DI}_{80}$ and $\mathrm{RDI}_{60}$ and $\mathrm{DI}_{60}$ were not significant in summer season but were significant in winter season. Also, difference in yield between $\mathrm{PRD}_{80}$ and $\mathrm{RDI}_{60}$ was significant in summer but not significant in winter season. This happened duo to the values of CWSI during the growth season for both previous treatments in winter season did not differ significantly.

On average, the yield of the winter season was higher than the corresponding one of the summer season.

Generally, the $60 \%$ level lower than $80 \%$ level of FI is logic, so $60 \%$ is too low. RDI upon using more water does not seem to be interesting in this schedule, investment in PRD does not seem to be paying.

Table 3: The water use efficiency (WUE) of potato $\left(\mathrm{kg} \mathrm{m}^{-3}\right)$ under different irrigation strategies during the growth seasons of winter and summer 2017 and 2018.

\begin{tabular}{lcccc}
\hline Irrigation & \multicolumn{4}{c}{ WUE $\left(\mathrm{kg} \mathrm{m}^{-3}\right)$} \\
\cline { 2 - 5 } technique & \multicolumn{2}{c}{2017} & \multicolumn{3}{c}{2018} \\
\cline { 2 - 5 } & Summer & Winter & Summer & Winter \\
\cline { 2 - 5 } FI & 6.33 & 17.99 & 7.53 & 14.56 \\
DI 80\% & 4.35 & 13.45 & 6.67 & 11.78 \\
DI 60\% & 3.54 & 9.62 & 3.15 & 7.94 \\
RDI 80\% & 6.22 & 17.06 & 7.28 & 13.78 \\
RDI 60\% & 3.63 & 14.62 & 4.96 & 10.74 \\
PRD 80\% & 5.42 & 15.91 & 6.89 & 12.87 \\
PRD 60\% & 3.60 & 10.78 & 4.82 & 8.72 \\
\hline
\end{tabular}


The highest values of WUE were achieved under the treatment FI, RDI 80, PRD 80 and RDI 60 in winter, while in summer the highest values were FI, RDI 80, PRD 80 and DI 80. The WUE decreased by about $141.76 \%$ and $2.5 \%$ in winter and summer seasons, respectively compared with FI. RDI 80 technique increased WUE by value of $7.15 \%$ in winter and $9.8 \%$ in summer compared with PRD 80, while RDI 60 increased also, WUE than PRD 60 by values ranged from $30.08 \%$ in winter and $2.01 \%$ in summer compared with PRD 60. Moreover, RDI 80 increased WUE than DI 80 by average values in winter and summer seasons of $22.4 \%$ while, RDI 60 increased WUE compared with DI 60 by values of $44.49 \%$ and $28.43 \%$ in winter and summer seasons, respectively. The values of water use efficiency are affected by both yield and water applied. The statistical analysis by one-way ANOVA test and Fisher LSD test show that, in winter season there were only significant differences between (PRD60 and RDI80), (PRD60 and FI), (PRD80 and DI60), (RDI80 and DI60) and (DI60 and FI). In summer season there were only significant differences between (PRD60 and RDI80), (PRD60 and FI), (PRD80 and DI60), (RDI80 and RDI60), (RDI60 and FI), (RDI80 and DI60) and (DI60 and FI).

Summer season decreased WUE by about $141.76 \%$ than winter season. RDI technique decreased WUE by value of $4.45 \%$ and $26.84 \%$ than FI under RDI 80 and RDI 60, respectively.

Generally, from the previous results, it can be decided that regulated Deficit irrigation integrated with subsurface drip irrigation for increasing the WUE, also CWSI is a helpful technique for managing the Deficit irrigation techniques.

\section{CONCLUSIONS}

The main results of this study show that, the value soil water content under the studied irrigation treatments ranged from 0.26 to 0.33 in summer and 0.31 to 0.40 in winter and the best values of SWC were under RDI80 followed by PRD80. CWSI took the same trend of SWC. RDI 80 achieved the highest values of yield and WUE compared with the FI. So, it can be recommend that the regulated Deficit irrigation integrates with subsurface drip irrigation for increasing the WUE, also CWSI is a helpful technique for managing the Deficit irrigation techniques. 


\section{A KNOWLAGENT}

The author thanks ASRT and ERANETMED "is funded by the European Commission's 7th Framework Program" for supporting this study, which carried out under the project of "Water Saving in Agriculture: technological developments for the sustainable management of limited water resources in the Mediterranean area".

\section{REFERENCES}

Badr, M. A., Hussein, S. D., El-Tohamy, W. A., and Gruda, N. (2010). Efficiency of Subsurface Drip Irrigation for Potato Production Under Different Dry Stress Conditions. Gesunde Pflanzen, 62(2), 63-70.

Buendía, B., Allende, A., Nicolás, E., Alarcón, J. J., and Gil, M. I. (2008). Effect of Regulated Deficit Irrigationi and Crop Load on the Antioxidant Compounds of Peaches. Journal of Agricultural and Food Chemistry, 56(10), 3601-3608.

Colaizzi, P. D., Barnes, E. M., Clarke, T. R., Choi, C. Y., and Waller, P. M. (2003). Estimating soil moisture under low frequency surface irrigationi using crop water stress index. Journal of Irrigationi and Drainage Engineering-asce, 129(1), 27-35.

Costa, M., Ortuño, M. F., and Chaves, M. (2007). Deficit Irrigation as a Strategy to Save Water: Physiology and Potential Application to Horticulture. Journal of Integrative Plant Biology - J INTEGR PLANT BIOL, 49, 1421-1434. doi:10.1111/j.16729072.2007.00556.x

Erdem, T., Orta, A. H., Erdem, Y., and Okursoy, H. (2005). Crop water stress index for potato under furrow and drip irrigation systems. Potato Research, 48, 49-58.

Geerts, S., and Raes, D. (2009). Deficit irrigation as an on-farm strategy to maximize crop water productivity in dry areas. Agricultural Water Management, 96(9), 1275-1284.

Idso, S. B., Jackson, R. D., Pinter, P., Reginato, R. J., \& Hatfield, J. (1981). Normalizing the stress-degree-day parameter for 
environmental variability. Agricultural Meteorology, 24, 45-55. doi:10.1016/0002-1571(81)90032-7

Romero, P., Botía, P., and Garcia, F. (2004). Effects of regulated deficit irrigationi under subsurface dripi irrigationi conditions on water relations of mature almond trees. Plant and Soil, 260, 155-168.

Wang, J., Kang, S., Li, F., Zhang, F., Li, Z., and Zhang, J. (2008). Effects of alternate partial root-zone irrigationi on soil microorganism and maize growth. Plant and Soil, 302, 45-52.

\section{الملخص العربى}

مؤشر الإجهاد المائي لمحصول البطاطس تحت نظام الري بالتتقيط تحت السطحي

$$
\text { (أبو سريع أ. فرج" }
$$

ندرة المياه وبالأخص في المناطق الجافة وشبه الجافة يلعب دور ا كبير ا في تغيير السياسات المائية للدول ومصر من اهم هذه الدول تأثر ا بهذه المشكلة. ومن اهم الطرق التي يمكن اتباعها للحفاظ

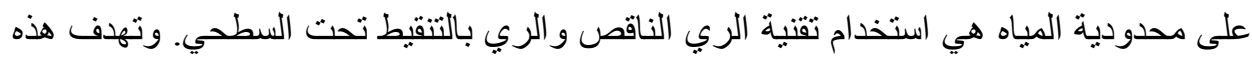

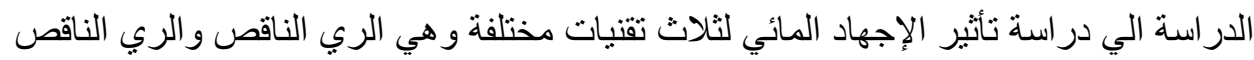
المنظم و الجفاف الجزئي لمنطقة الجزور تحت مستويان • ^^\% و • ؟\% من كامل الاحتياجات المائية

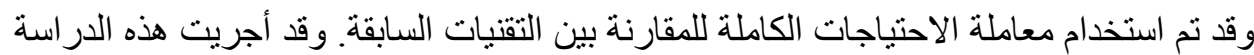
على محصول البطاطس (صنف اسبونتا) خلال الموسمين الصيفي و الثتوي و أجريت خلال عامان

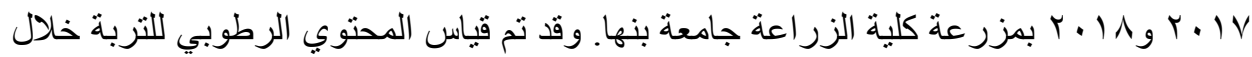
مر احل النمو المختلفة للنبات بعد يومان من الري وكذلك تم قياس درجة حرارة الهواء و الغطاء النباتي لحساب معامل الإجهاد المائي. وتم جمع المحصول مرة و احدة في نهاية الموسم لكل مكررة

$$
\text { على حدة. }
$$

$$
\text { وقد اوضحت اهم النتائج الاتي: }
$$

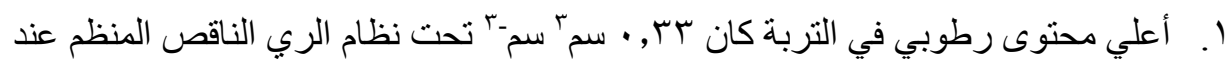

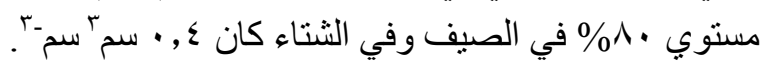

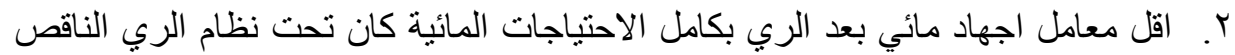

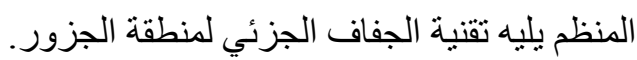

r. اعلي إنتاجية وكفاءة استخدام للمياه بعد الري بكامل الاحتياجات المائية كانت تحت نظام

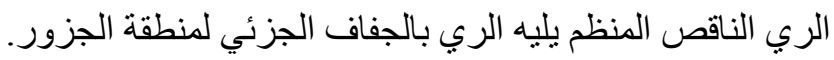

مدرس هندسة النظم الزراعية والحيوية بكلية الزراعة جامعة بنها 


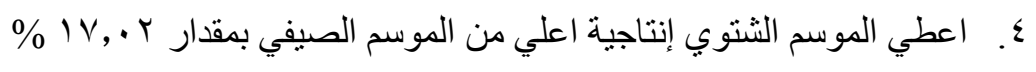

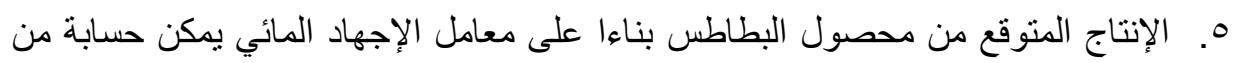

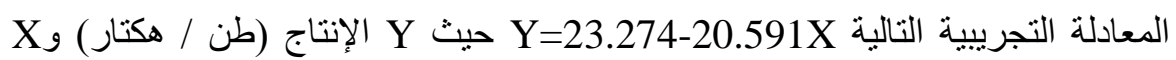

$$
\text { معامل الإجهاد المائي. }
$$

بشكل عام من واقع نتائج التجربة يمكن التوصية بأهمية استخدام تقنية الري الناقص المنظم

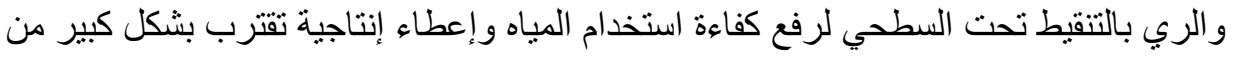
الري بكامل الاحتياجات المائية. 